\title{
First Subject Treated Date Time
}

National Cancer Institute

\section{Source}

National Cancer Institute. First Subject Treated Date Time. NCI Thesaurus. Code C142562.

The date and time when the first individual is administered the test article or placebo in a clinical trial. 